\title{
Prediction of the excessive perioperative bleeding in patients undergoing coronary artery bypass grafting: Role of aspirin and platelet glycoprotein Illa polymorphism
}

W. Morawski, MD, PhD, ${ }^{a}$ M. Sanak, MD, PhD, ${ }^{\text {b }}$ M. Cisowski, MD, PhD, ${ }^{a}$ M. Szczeklik, MD, ${ }^{a}$ W. Szczeklik, MD, PhD, J. Dropinski, MD, PhD, ${ }^{b}$ T. Waclawczyk, MD, ${ }^{a}$ R. Ulczok, MD, and A. Bochenek, MD, PhD ${ }^{a}$

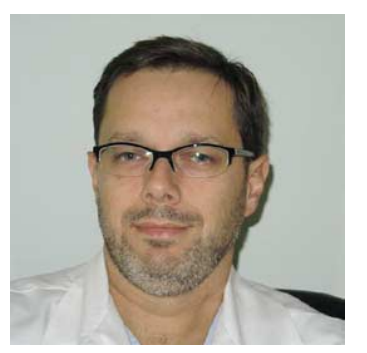

From the First Cardiac Surgery Department, Medical University of Silesia, Katowice, Poland, ${ }^{\mathrm{a}}$ and the Department of Medicine, Jagellonian University School of Medicine, Krakow, Poland. ${ }^{\text {b }}$

Supported by KBN (State Committee for Scientific Research).

Received for publication Nov 30, 2004; revisions received Feb 12, 2005; accepted for publication Feb 24, 2005.

Address for reprints: Wlodzimierz Morawski, MD, PhD, 45/47 Ziolowa St, 40-635, Katowice, Poland (E-mail: wmorski@ wp.pl).

J Thorac Cardiovasc Surg 2005;130:791-6

$0022-5223 / \$ 30.00$

Copyright $\odot 2005$ by The American Association for Thoracic Surgery

doi:10.1016/j.jtcvs.2005.02.041
Objective: The presence of the glycoprotein IIIa allele $\mathrm{Pl}^{\mathrm{A} 2}$ is associated with enhanced thrombin formation and an impaired antithrombotic action of aspirin, which could favor coronary thrombosis. We wondered whether $\mathrm{Pl}^{\mathrm{A} 1 / \mathrm{A} 2}$ genetic polymorphism could affect the postoperative bleeding in patients undergoing coronary artery bypass grafting. We also aimed to assess the effects of aspirin pretreatment and to ascertain the value of platelet function studies as predictors of postoperative bleeding.

Methods: In a randomized, double-blind study, patients undergoing coronary artery bypass grafting were pretreated with a 150-mg dose of aspirin orally 12 and 3 hours before surgery $(\mathrm{n}=51,41$ elective) or with placebo $(\mathrm{n}=51,43$ elective). The hemostasis was monitored by Simplate (bioMérieux, Inc, Durham, NC) bleeding time and capillary closure time (platelet function analyzer PFA 100; Sysmex UK Ltd, Milton Keynes, United Kingdom). Postoperative bleeding and blood products transfusions were recorded. The glycoprotein IIIa polymorphism was analyzed.

Results: Bleeding was significantly greater in $\mathrm{Pl}^{\mathrm{A} 1}$ homozygotes from control group. Blood loss was significantly greater (by 25\%) in aspirin group. The volume of blood products transfusions in aspirin patients was significantly larger (by 137\%). When subjects were stratified accordingly to blood platelet glycoprotein IIb/IIIa genotype, in the aspirin group $\mathrm{Pl}^{\mathrm{A} 2}$ carriers had greater blood loss than $\mathrm{Pl}^{\mathrm{A} 1}$ homozygotes $(1858 \pm 932 \mathrm{~mL}$ vs $1216 \pm 525 \mathrm{~mL}, P<.05)$.

Conclusion: $\mathrm{Pl}^{\mathrm{A} 1}$ homozygotes normally had a greater risk of perioperative bleeding. Capillary closure time had no advantage relative to Simplate bleeding time in predicting postoperative blood loss. Aspirin pretreatment revealed no beneficial effects and resulted in increased postoperative bleeding and requirement for blood product transfusions after coronary artery bypass grafting in patients with stable angina. It was most unfavorable for $\mathrm{Pl}^{\mathrm{A} 2}$ carriers.

A spirin is a widely established drug in the treatment of coronary artery disease. It has been proved to decrease the risk of cardiovascular events, especially in coronary artery disease. According to the American College of Cardiology and the American Heart Association, it should be used by every patient at risk for coronary artery disease unless there are specific contraindications.

The benefits of an early introduction of aspirin after coronary artery bypass grafting (CABG) have been well documented. The recent American College of Cardiology and American Heart Association Practice Guidelines for $\mathrm{CABG}^{1}$ strongly recommend aspirin as a drug of choice against early vein graft closure in the first postoperative year ${ }^{2,3}$ and advice its introduction in the first 6 hours after the surgery because it reduces risk of myocardial infarction, stroke, renal failure, and bowel infarction. ${ }^{4}$ Early postoperative introduction of aspirin is associated with 
improved early graft patency. ${ }^{5}$ Postoperative aspirin therefore is now a criterion standard and should be administered routinely shortly after surgery.

In contrast, aspirin administered before surgery increases the postoperative blood loss because of its antiplatelet action. ${ }^{6}$ It is also associated with increased risk of transfusion, reexploration for bleeding, and prolonged wound healing time. ${ }^{1}$ However, there are some data suggesting that this is not true for all patients. ${ }^{7-9}$ Thus some patients could probably benefit from preoperative use of aspirin also. ${ }^{10,11}$

If possible, aspirin should be stopped 7 to 10 days before the surgery, and this is often a problem. Many patients with acute coronary syndromes receive aspirin because its benefits outweigh the risk of postoperative bleeding. If an urgent operation is required, it is not possible to withdraw the aspirin.

The emerging data point to an important role of platelets early after $\mathrm{CABG}$, separate and distinct from their contributing role in long-term patency of grafts. The formation of occlusive platelet aggregates involves the cross-linking of activated glycoprotein IIb/IIIa receptors on adjacent platelets by fibrinogen and other macromolecular ligands. A single nucleotide transition at position 1565 in exon 2 of the gene encoding glycoprotein IIIa leads to its diallelic polymorphism $\left(\mathrm{Pl}^{\mathrm{A} 1 / \mathrm{A} 2}\right)$. $\mathrm{Pl}^{\mathrm{A} 2}$ is present in $20 \%$ to $30 \%$ of the white population and is associated with enhanced thrombin formation and an impaired antithrombotic action of aspirin, which might favor coronary thrombosis in $\mathrm{Pl}^{\mathrm{A} 2}$ carriers.

This study was based on two hypotheses, that $\mathrm{Pl}^{\mathrm{A} 1 / \mathrm{A} 2}$ polymorphism influences bleeding after $\mathrm{CABG}$ and that platelet function studies have predictive value for perioperative blood loss in patients who were taking aspirin when they were operated on.

\section{Patients and Methods}

The randomized, double-blind study included two groups with a total of 102 patients with coronary artery disease referred for CABG. The vast majority of cases were elective ( $80.4 \%$ vs $84.3 \%$, aspirin vs control group, respectively). Ten patients in the aspirin group and 8 in the control group underwent operation on an urgent basis, and they were treated with preoperative intravenous nitroglycerin and heparin. Patients were assigned to the treatment groups (aspirin vs control) with a computer pseudorandom number generator. Odd and even numbers were used to assign aspirin and placebo, respectively, and the study team was not aware of the number assigned. After completion of the study, the numbers were decoded and the patients were analyzed according to treatment (aspirin or placebo). The study medication was prepared in the pharmacology department of our center. None of the patients was treated with any antiplatelet agents for 10 days before the operation. In the first group, patients $(\mathrm{n}=51)$ received $150 \mathrm{mg}$ aspirin 12 hours and 3 hours before surgery; patients from the second group $(n=51)$ received placebo. The study was approved by the university ethics committee, and all patients gave informed consent to participate.
All patients were anesthetized under the same protocol. Median sternotomy, cardiopulmonary bypass (CPB), moderate hypothermia $\left(28^{\circ} \mathrm{C}\right)$, and blood cardioplegia were used. Intravenous heparin was administered (300 U/kg) before ascending aorta cannulation. Additional doses of heparin $(100 \mathrm{U} / \mathrm{kg})$ were given after $60 \mathrm{~min}$ utes of CPB. Activated clotting time (ACT) was kept at greater than 480 seconds. Once the patient was weaned from CPB, protamine sulfate $(3 \mathrm{mg} / \mathrm{kg}$ ) was given to reverse the anticoagulant action of heparin. If a patient required mechanical support (intraaortic balloon pump), additional doses of intravenous heparin were given to maintain ACT at the level of 180 to 200 seconds. In such instances, no reversal treatment (protamine sulfate) was administered unless the patient had excessive bleeding.

Patient demographic data (sex, age, weight, height), medical history (history of stroke, hypertension, diabetes, chronic obstructive pulmonary disease, renal failure, or peripheral artery disease and Canadian Cardiovascular Society and New York Heart Association functional classes) were obtained before the operation.

During and after the operation, CPB time, crossclamp time, number of grafts, use of left internal thoracic artery, need for inotropes (dopamine, epinephrine), and mechanical (intra-aortic balloon pump) support were recorded. Serum levels of creatinine kinase and its heart fraction (CK-MB) and troponin I were monitored and recorded before the operation and on days 0,1 , and 3 . When the previously mentioned markers were elevated, they were assessed during another 2 consecutive days. Electrocardiography (ECG) was recorded during admission, on the day of the operation, and on postoperative days $0,1,3$, and 7 . Perioperative myocardial infarction was diagnosed when one of the following was observed: new $\mathrm{Q}$ wave in ECG, CK-MB greater than $50 \mathrm{U}$ with ECG changes, or 4-fold increase in CK-MB level independent of ECG changes. The need for reexploration for bleeding (differentiation between surgical bleeding and oozing), postoperative renal failure (postoperative serum creatinine level $>2.0 \mathrm{mg} / \mathrm{dL}$ or elevation of $>50 \%$ over baseline), infections (deep sternal site infection), need for prolonged mechanical ventilation (more than 3 days according to the analysis performed by Branca and colleagues ${ }^{12}$ ), length of stay in the intensive care unit (ICU), length of hospitalization, and deaths were recorded.

Before and after the operation (days 0, 1, 3, and 7), whole blood cell count was recorded. After operation, immediately after transfer of the patient to the ICU, and 24 hours later, Simplate R (bioMérieux, Inc, Durham, NC) bleeding time was measured. Before the operation, 10 and 30 minutes after establishment of $\mathrm{CPB}$, after transfer of the patient to the ICU and 24 hours after surgery, closure time was measured with the PFA-100 analyzer (Sysmex UK Ltd, Milton Keynes, United Kingdom). This is an ex vivo study in which whole blood is sucked into capillary tube. The high shear-stress rate causes platelet activation and aggregation. Two types of membranes are used, coated with epinephrine and collagen and with adenosine and collagen, both potent platelet activating agents. The analyzer measures the time in which blood clots inside the capillary tube (closure time). ${ }^{13}$

The glycoprotein IIIa polymorphism was analyzed after the operation. Genomic DNA samples were obtained by standard methods from peripheral blood leukocytes of the subjects studied. DNA concentration was quantified with spectrophotometry. A 282-base pair fragment from exon 2 and intron 2 of the glyco- 
protein IIIa gene coding region were amplified with specific primers by using polymerase chain reaction. Reaction products were digested with $M s p I$ restriction endonuclease, and 125- and 157base pair fragments were seen only if $\mathrm{Pl}^{\mathrm{A} 2}$ allele was present because of the $M s p$ I restriction enzyme cutting site at the thymine to cytosine replacement. Genotypes were scored on $1.5 \%$ agarose gel (SFR Agarose; Amresco, Solon, Ohio) and stained with $0.5 \mu \mathrm{g} / \mathrm{mL}$ ethidium bromide under a UV transilluminator.

Intraoperative blood loss was measured by quantifying the amount of blood in the external suction reservoir and by weighing the swabs. Postoperative blood loss was recorded as the volume of chest tube drainage connected to at four-chamber Sherwood collection bag that was kept under suction of $-15 \mathrm{~mm} \mathrm{H}_{2} \mathrm{O}$ for the first 12 hours after the operation.

A hemoglobin level below $8.0 \mathrm{~g} / \mathrm{dL}$ was the threshold for blood transfusion. The numbers of units transfused of packed red blood cells, fresh-frozen plasma, and platelets was recorded. No antifibrinolytic agents ( $\epsilon$-aminocaproic acid, tranexamic acid) or serine protease inhibitors (aprotinin) were used in the study.

Platelet count, prothrombin time, and ACT were measured directly after transfer of the patient to the ICU. If ACT was elevated, an additional dose of protamine sulfate was administered. In case of elevated prothrombin time, patient was treated with fresh-frozen plasma $(10-15 \mathrm{~mL} / \mathrm{kg})$. If excessive bleeding persisted or platelet count was less than 80,000 cells $/ \mu \mathrm{L}$ after correction of these clotting abnormalities, platelet transfusion was done. The dose of platelet concentrate was individually calculated for every patient by the blood bank. The calculations were based on body weight, height, and platelet count. From the first postoperative day on, $150 \mathrm{mg}$ of aspirin was administered orally.

\section{Statistical Analysis}

Statistical evaluation was performed with a personal computer and Statistica 5.5 software (StatSoft Inc, Tulsa, Okla). Summary statistics were expressed as means and SDs or 95\% confidence intervals. The general linear model, including analysis of variance (the Kolomogorov-Smirnov variant) and multivariate analysis of variance, was used. The $\chi^{2}$ approach for testing Hardy-Weinberg equilibrium was used for genotype frequency analysis and for comparison of polymorphism frequency between the groups studied.

\section{Results}

We studied 102 subjects, 51 study patients who received aspirin preoperatively and 51 control patients who did not received the drug before $\mathrm{CABG}$. Preoperative patient characteristics are presented in Table 1, and data related to CABG procedure are presented in Table 2. Three patients died in the early postoperative period, 2 in the study group and 1 in the control group. One patient in the aspirin group died of sepsis and multiorgan failure and the other of pneumonia, renal insufficiency, and congestive heart failure. One patient in the control group died of perioperative myocardial infarction resistant to pharmacologic and mechanical (intra-aortic balloon pump) support. Two patients in the control group and 4 in the aspirin group required reexploration for bleeding $(P=.674)$. In all cases, the
TABLE 1. Preoperative patient characteristics

\begin{tabular}{|c|c|c|c|}
\hline & $\begin{array}{l}\text { Aspirin } \\
\text { group }\end{array}$ & $\begin{array}{l}\text { Control } \\
\text { group }\end{array}$ & $\begin{array}{c}P \\
\text { value }\end{array}$ \\
\hline Sex (male/female) & $45: 6$ & $42: 9$ & .404 \\
\hline Age $(y$, mean $\pm S D)$ & $61.3 \pm 8.4$ & $61.1 \pm 8.4$ & .879 \\
\hline $\begin{array}{l}\text { Body mass index }\left(\mathrm{kg} / \mathrm{m}^{2}\right. \\
\text { mean } \pm \mathrm{SD})\end{array}$ & $6.4 \pm 3.1$ & $27.0 \pm 2.9$ & .426 \\
\hline Hypertension (\%) & 66.7 & 56.9 & .248 \\
\hline Diabetes (\%) & 17.6 & 19.6 & .8 \\
\hline $\begin{array}{l}\text { Left ventricular ejection } \\
\text { fraction }(\%)\end{array}$ & $55.1 \pm 8.4$ & $55.7 \pm 8.4$ & .357 \\
\hline Left main stem disease (No.) & 3 & 9 & .124 \\
\hline $\begin{array}{l}\text { Chronic obstructive } \\
\text { pulmonary disease (\%) }\end{array}$ & 5.9 & 3.9 & $>.999$ \\
\hline Renal insufficiency (\%) & 2 & 0.0 & $>.999$ \\
\hline $\begin{array}{l}\text { Peripheral vascular } \\
\text { disease }(\%)\end{array}$ & 2 & 3.9 & $>.999$ \\
\hline History of stroke (\%) & 2 & 0 & $>.999$ \\
\hline $\begin{array}{l}\text { New York Heart Association } \\
\text { class (mean } \pm \text { SD) }\end{array}$ & $1.81 \pm 0.55$ & $1.78 \pm 0.58$ & .5 \\
\hline $\begin{array}{l}\text { Canadian Cardiovascular } \\
\text { Society class } \\
\text { (mean } \pm \text { SD) }\end{array}$ & $3.3 \pm 0.4$ & $3.3 \pm 0.5$ & .259 \\
\hline $\begin{array}{l}\text { Patients with unstable } \\
\text { angina (No.) }\end{array}$ & 10 & 8 & .795 \\
\hline $\begin{array}{l}\text { Platelet count }\left(10^{3} \text { cells/ }\right. \\
\left.\mathrm{mm}^{3} \text {, mean } \pm S D\right)\end{array}$ & $222 \pm 208$ & $187 \pm 202$ & .111 \\
\hline
\end{tabular}

bleeding site was identified and surgically controlled. Eighteen patients in the aspirin group and 4 in the control group received platelet concentrate postoperatively $(P=.0129)$

$\mathrm{Pl}^{\mathrm{A} 1 / \mathrm{A} 2}$ polymorphism was ascertained in 51 patients in the aspirin group and in 51 control patients; in 3 cases, no DNA was available for genotyping. In the aspirin group, frequency of the $\mathrm{Pl}^{\mathrm{A} 2}$ allele was 10.8\%: 7 subjects were heterozygotic $\left(\mathrm{Pl}^{\mathrm{A} 1 / \mathrm{A} 2}\right)$ and 2 were homozygotic $\left(\mathrm{Pl}^{\mathrm{A} 2 / \mathrm{A} 2}\right)$. In the control group, the frequency of the $\mathrm{Pl}^{\mathrm{A} 2}$ allele was $17.7 \%$ : there were 15 heterozygotes $\left(\mathrm{Pl}^{\mathrm{A} 1 / \mathrm{A} 2}\right)$ and 1 homozygote $\left(\mathrm{Pl}^{\mathrm{A} 2 / \mathrm{A} 2}\right)$. The difference in $\mathrm{Pl}^{\mathrm{A} 2}$ allelic frequency between the groups was not significant.

Blood loss related to CABG was significantly greater (by $25 \%$ ) in the aspirin group than in the control group (Figure $1)$. This was reflected by a significantly larger (137\%) volume of blood product transfusions required during postoperative treatment of patients in the aspirin group (1.49 \pm 1.41 units vs $0.76 \pm 1.77$, aspirin vs control, $P=.021$ ). When subjects were stratified accordingly to blood platelet glycoprotein IIb/IIIa genotype, in the aspirin group $\mathrm{Pl}^{\mathrm{A} 2}$ carriers had greater blood loss than $\mathrm{Pl}^{\mathrm{A} 1}$ homozygotes (1858 $\pm 932 \mathrm{~mL}$ vs $1216 \pm 525 \mathrm{~mL}, P<.05)$. Interestingly, in the control group, this relation was reversed $(760 \pm 231$ vs $1138 \pm 656 \mathrm{~mL}, P<.05)$. Thus in $\mathrm{Pl}^{\mathrm{A} 1}$ homozygotes postoperative blood loss was not affected by aspirin administration, whereas in $\mathrm{Pl}^{\mathrm{A} 2}$ carriers bleeding increased by 
TABLE 2. Data related to CABG procedure

\begin{tabular}{|c|c|c|c|}
\hline & $\begin{array}{l}\text { Aspirin } \\
\text { group }\end{array}$ & $\begin{array}{l}\text { Control } \\
\text { group }\end{array}$ & $\begin{array}{c}P \\
\text { value } \\
\end{array}$ \\
\hline CPB time (min, mean $\pm S D$ ) & $87.0 \pm 24.1$ & $85.6 \pm 21.0$ & .389 \\
\hline $\begin{array}{l}\text { Aortic crossclamp time (min, } \\
\text { mean } \pm S D)\end{array}$ & $46.9 \pm 19.0$ & $48.8 \pm 13.0$ & .427 \\
\hline No. of grafts (mean \pm SD) & $3.0 \pm 0.8$ & $2.9 \pm 0.8$ & .354 \\
\hline $\begin{array}{l}\text { Left internal thoracic artery } \\
\text { use }(\%)\end{array}$ & 82.3 & 80.4 & .392 \\
\hline $\begin{array}{l}\text { Inotropic support (excluding } \\
\text { dopamine) }(\%)\end{array}$ & 29.4 & 13.7 & .045 \\
\hline IABP (\%) & 9.8 & 5.9 & .713 \\
\hline $\begin{array}{l}\text { CK-MB } 12 \text { postoperative } h \\
(\mathrm{U} / \mathrm{L}, \text { mean } \pm \mathrm{SD})\end{array}$ & $62.2 \pm 51.5$ & $52.5 \pm 40.5$ & .412 \\
\hline $\begin{array}{l}\text { Troponin I } 12 \text { postoperative } \mathrm{h} \\
(\mathrm{ng} / \mathrm{mL} \text {, mean } \pm \mathrm{SD})\end{array}$ & $5.21 \pm 3.07$ & $3.8 \pm 3.16$ & .322 \\
\hline Myocardial infarction (\%) & 3.9 & 3.9 & .61 \\
\hline $\begin{array}{l}\text { Reexploration for bleeding } \\
(\%)\end{array}$ & 7.8 & 3.9 & .674 \\
\hline Wound infection (\%) & 3.9 & 0 & .475 \\
\hline $\begin{array}{l}\text { Prolonged assisted } \\
\text { ventilation (\%) }\end{array}$ & 3.9 & 0 & .475 \\
\hline ICU stay (h, mean $\pm \mathrm{SD}$ ) & $37.8 \pm 54.1$ & $24.7 \pm 3.8$ & .371 \\
\hline Hospital stay (d, mean \pm SD) & $7.6 \pm 2.0$ & $7.3 \pm 1.0$ & .378 \\
\hline Death $(\%)$ & 3.9 & 2 & $>.999$ \\
\hline Blood loss $(\mathrm{mL}$, mean $\pm \mathrm{SD})$ & $1281 \pm 598$ & $1008 \pm 572$ & .018 \\
\hline $\begin{array}{l}\text { Blood products transfused } \\
\quad(U, \text { mean } \pm S D)\end{array}$ & $1.49 \pm 1.41$ & $0.76 \pm 1.77$ & .021 \\
\hline $\begin{array}{l}\text { Platelet count first day after } \\
\text { CABG }\left(10^{3} \text { cells } / \mathrm{mm}^{3},\right. \\
\text { mean } \pm S D\end{array}$ & $137 \pm 39$ & $139 \pm 43$ & .46 \\
\hline $\begin{array}{l}\text { Platelet count third day after } \\
\text { CABG }\left(10^{3} \text { cells } / \mathrm{mm}^{3},\right. \\
\text { mean } \pm \mathrm{SD}\end{array}$ & $260 \pm 74$ & $289 \pm 94$ & .417 \\
\hline $\begin{array}{l}\text { Platelets count seventh day } \\
\text { after CABG }\left(10^{3} \text { cells } / \mathrm{mm}^{3}\right. \\
\text { mean } \pm S D\end{array}$ & $398 \pm 109$ & $411 \pm 80$ & .423 \\
\hline
\end{tabular}

$152 \%$ after aspirin treatment preceding CABG (Figure 1) After exclusion of the patients who underwent reexploration for bleeding, blood loss and transfusion requirements remained different between groups (Table 3).

Preoperative evaluation bleeding time (Simplate R) or capillary occlusion time (PFA-100) failed to correlate with postoperative bleeding. However, both Simplate and PFA100 measurements repeated immediately after CABG were predictive of blood loss. Correlation between Simplate time and blood loss was highly significant $(\tau=0.201 ; P<.005)$, while PFA-100 closure time correlation with blood loss was weaker $(\tau=0.152 ; P<.05$ for epinephrine, $\tau=0.146 ; P$ $<.04$ for adenosine diphosphate [ADP]). The platelet levels dropped after $\mathrm{CPB}$, but there were no differences between groups at any time. Thereafter, platelet counts increased to 260,000 and 289,000 cells $/ \mathrm{mm}^{3}$ at day 3 and 399,000 and
TABLE 3. Data concerning blood loss and blood products transfused after exclusion of patients undergoing reexploration for bleeding

\begin{tabular}{lccc}
\hline & $\begin{array}{c}\text { Aspirin } \\
\text { group }\end{array}$ & $\begin{array}{c}\text { Control } \\
\text { group }\end{array}$ & $\begin{array}{c}\boldsymbol{P} \\
\text { value }\end{array}$ \\
\hline $\begin{array}{l}\text { Blood loss (mL, mean } \pm \text { SD) } \\
\text { Red blood packed cells } \\
\quad 1(\mathrm{U}, \text { mean } \pm \text { SD) }\end{array}$ & $1.41 \pm 1.41$ & $0.5 \pm 0.922$ & .0003 \\
$\begin{array}{l}\text { Fresh-frozen plasma } \\
\quad(U, \text { mean } \pm \text { SD) }\end{array}$ & $1.19 \pm 1.61$ & $0.62 \pm 1.11$ & .028 \\
$\begin{array}{l}\text { Platelets (U, mean } \pm \text { SD) } \\
\text { latel }\end{array}$ & $0.39 \pm 0.65$ & $0.08 \pm 0.35$ & .005 \\
\hline
\end{tabular}

411,000 cells $/ \mathrm{mm}^{3}$ at day 7 (aspirin and control groups, respectively; Figure 2). No postoperative differences in CK-MB and troponin I levels were observed between the groups.

\section{Discussion}

Recent American College of Cardiology and American Heart Association Practice Guidelines updates for $\mathrm{CABG}^{1}$ acknowledged that increased postoperative bleeding and risk for reexploration associated with aspirin are outweighed by the benefits of preoperative aspirin use. The aim of study was to investigate whether a common $\mathrm{Pl}^{\mathrm{A} 1 / \mathrm{A} 2}$ polymorphism, functionally associated with anticlotting response to aspirin, could affect postoperative risk for patients undergoing elective CABG. The study was designed to evaluate preoperative and postoperative hemostatic measures along with risk outcomes in a series of aspirin-treated and control patients undergoing $\mathrm{CABG}$ intervention. Genotyping of $\mathrm{Pl}^{\mathrm{A} 1 / \mathrm{A} 2}$ polymorphism was completed after patient recruitment and after hospital discharge. Ex vivo studies on thrombin generation ${ }^{14}$ had documented that $\mathrm{Pl}^{\mathrm{A} 2}$ carriers were more likely to be refractory to benefits of aspirin therapy.

The platelet arachidonic acid cyclooxygenase pathway, which is irreversibly inhibited by aspirin, is one of several mechanisms amplifying prothrombotic response of these blood particles. During extracorporeal circulation, shear stress is the overwhelming stimulus for platelet activation. ${ }^{15}$ It has been demonstrated that $\mathrm{Pl}^{\mathrm{A} 2}$-positive platelets in healthy subjects present a hyperresponsive status, manifested by increased glycoprotein IIb/IIIa fibrinogen binding and lower ADP activation threshold, resulting in increased adhesion, spreading, aggregation, and clot retraction. Aspirin can impair thrombin generation, which takes place on the surface of activated platelets. Thus in the presence of aspirin, any relevant variability caused by $\mathrm{Pl}^{\mathrm{A} 1 / \mathrm{A} 2}$ polymorphism should be exposed during a surgical procedure characterized by massive platelet activation. Results of this study confirm relatively low risk imposed by preoperative as- 


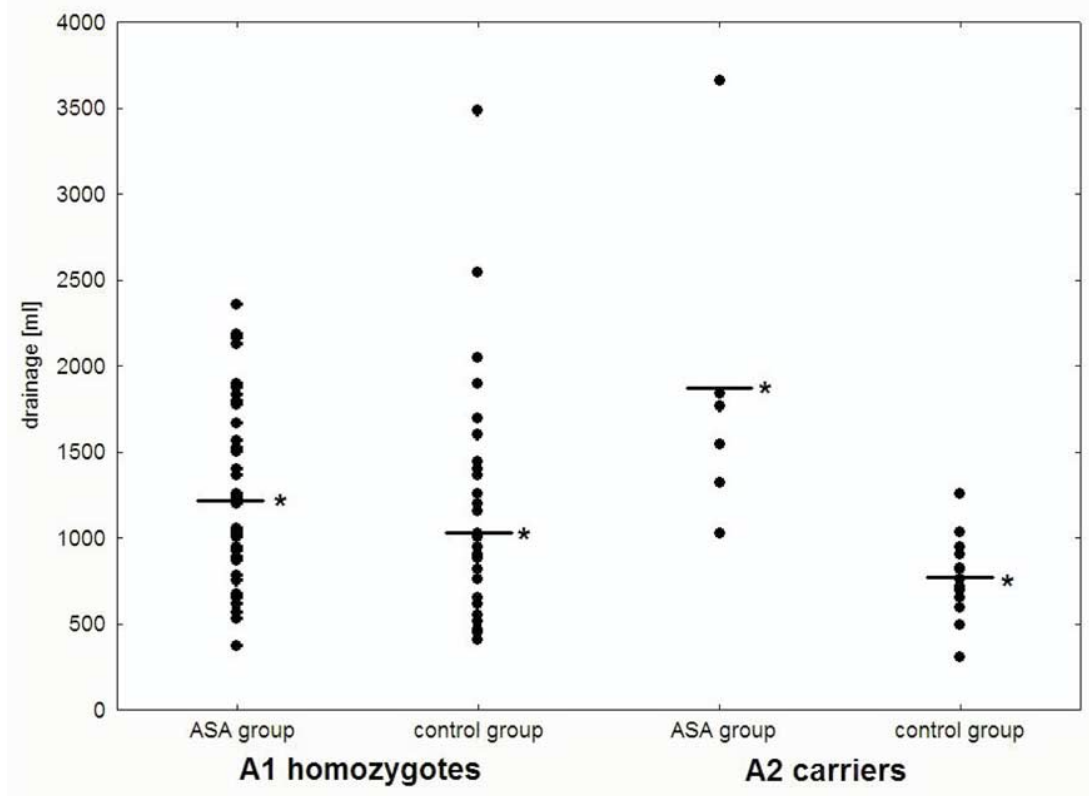

Figure 1. Blood loss (in milliliters) in preoperative aspirin (ASA) and control groups. Asterisks indicate mean. $P=.015$ between $\mathrm{PI}^{\mathrm{A1}}$ homozygotes and $\mathrm{PI}^{\mathrm{A2}}$ carriers in aspirin group.

pirin in patients undergoing $\mathrm{CABG}$. In $\mathrm{Pl}^{\mathrm{A} 1}$ homozygotes, no excess bleeding or need for transfusions was observed. Patients carrying the $\mathrm{Pl}^{\mathrm{A} 2}$ allele, however, in addition to a blunted response to aspirin in general, in the particular case of CABG demonstrated a wide spectrum of consequences related to a single amino acid substitution in IIIa integrin. Without aspirin, $\mathrm{Pl}^{\mathrm{A} 2}$ carriers had diminished blood loss, in agreement with the genetically determined hyperresponsive status of their platelets. Un- expectedly, preoperative aspirin increased blood loss in the $\mathrm{Pl}^{\mathrm{A} 2}$ group by $152 \%$, indicating that cyclooxygenase pathway plays important role in fine-tuning blood clotting. It is possible that hyperreactive $\mathrm{Pl}^{\mathrm{A} 2}$ platelets are particularly sensitive to shear stress but without thromboxane generation cannot provide sufficient hemostasis. An antiplatelet regimen achieved by concurrent use of clopidogrel and aspirin resulted in additional protection against acute vascular events in the Clopidogrel in Un-

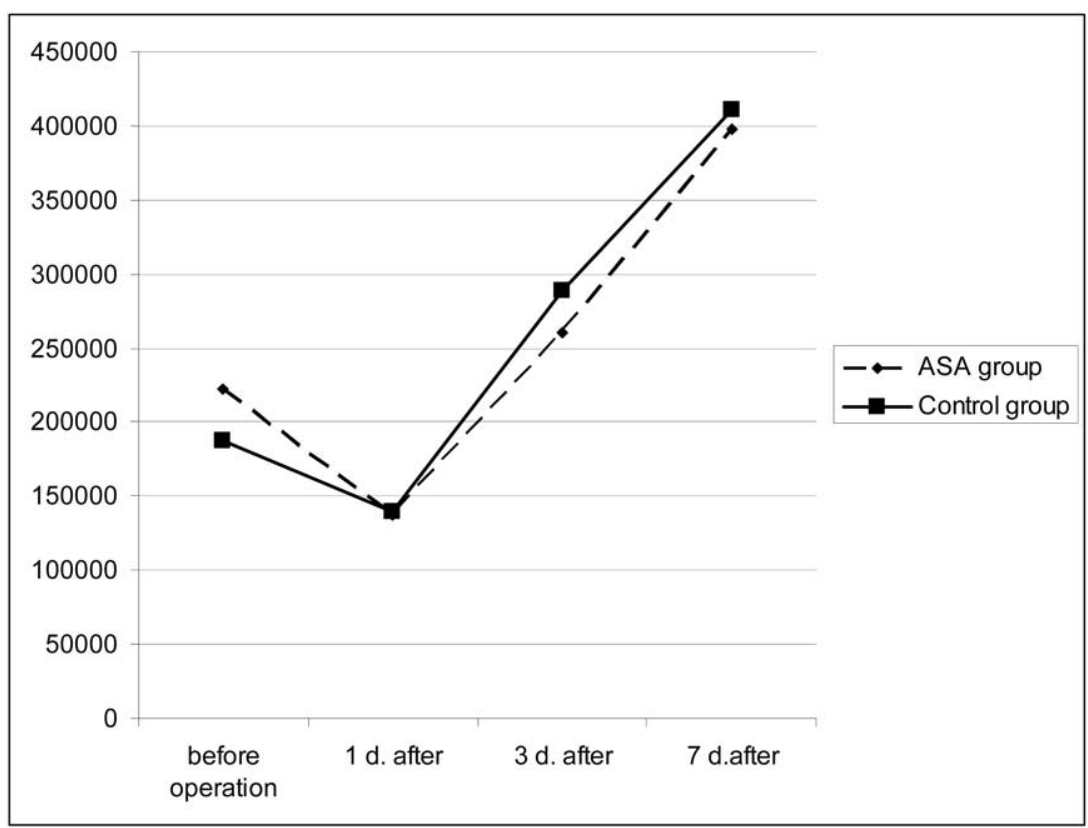

Figure 2. Platelet count (in cells per cubic milliliter) in preoperative aspirin (ASA) and control groups. 
stable angina to prevent Recurrent Events (CURE) study. ${ }^{16}$ Perhaps this effective antiplatelet therapy of cyclooxygenase inhibition and purine receptor blockade can prevent platelets wear off during $\mathrm{CABG}$, when continuous shear stress washes ADP out of platelets. In the patients studied, the numbers of platelets before and after CABG did not differ significantly. Thus the possibility of bleeding related to thrombocytopenia could be excluded. Further studies on platelet activation markers and ADP platelet content during $\mathrm{CABG}$ should provide more insight into this unfavorable pharmacogenetic interaction between platelet $\mathrm{Pl}^{\mathrm{A} 1 / \mathrm{A} 2}$ polymorphism and risk imposed by preoperative aspirin in patients undergoing CABG. For $\mathrm{Pl}^{\mathrm{A} 2}$ carriers receiving aspirin, one should consider the use of special precautions to minimize bleeding tendency after CABG. One of the possibilities is antithrombolytic therapy (aprotinin, $\epsilon$-aminocaproic acid) in this group, which might be expected to effectively diminish postoperative blood loss. ${ }^{17,18}$ Alternatively, hemostasis could be secured through scheduled transfusion of freshfrozen plasma and platelet concentrate.

\section{Limitations of the Study}

The limited number of subjects studied did not allow us to evaluate major adverse clinical events and major cardiac and cerebral events. In fact, we observed only 3 deaths and 8 perioperative myocardial infarctions. Those events did not correlate with discontinuation of aspirin in patients operated on urgently; however this observation lacks statistical power. The examined blood loss and transfusion requirements could in fact be further divided as simple end points. Because of the limited number of $\mathrm{Pl}^{\mathrm{A} 2}$ carriers in the study, we were not able to analyze simple clinical end points.

\section{Conclusions}

$\mathrm{Pl}^{\mathrm{A} 1}$ homozygotes normally had greater risk of perioperative bleeding than $\mathrm{Pl}^{\mathrm{A} 2}$ carriers. Capillary closure time determined with the PFA-100 analyzer showed no advantage relative to traditional bleeding time in predicting postoperative blood loss. Aspirin pretreatment 12 and 3 hours before surgery revealed no beneficial effects and in fact resulted in increased postoperative bleeding and need for blood products transfusions. For patients positive for platelet $\mathrm{Pl}^{\mathrm{A} 2}$ polymorphism receiving aspirin at operation, special security measures should be considered, such as antifibrinolytic drugs or fresh-frozen plasma or platelet concentrate transfusions.

\section{References}

1. Eagle KA, Guyton RA, Davidoff R, Edwards FH, Ewy GA, Gardner TJ, et al. ACC/AHA 2004 guideline update for coronary artery bypass graft surgery: a report of the American College of Cardiology/American Heart Association Task Force on Practice Guidelines (Committee to Update the 1999 Guidelines for Coronary Artery Bypass Graft Surgery). Circulation. 2004;110:e340-437.

2. Chesebro JH, Fuster V, Elveback LR, Clements IP, Smith HC, Holmes DR Jr, et al. Effect of dipyridamole and aspirin on late vein-graft patency after coronary bypass operations. N Engl J Med. 1984;310: 209-14.

3. Lorenz RL, Schacky CV, Weber M, Meister W, Kotzur J, Reichardt B, et al. Improved aortocoronary bypass patency by low-dose aspirin (100 $\mathrm{mg}$ daily). Effects on platelet aggregation and thromboxane formation. Lancet. 1984;8389:1261-4.

4. Mangano DT, Multicenter Study of Perioperative Ischemia Research Group. Aspirin and mortality from coronary bypass surgery. $N$ Engl J Med. 2002;347:1309-17.

5. Gavaghan TP, Gebski V, Baron DW. Immediate postoperative aspirin improves vein graft patency early and late after coronary artery bypass graft surgery. Circulation. 1991;83:1526-33.

6. Kallis P, Tooze JA, Talbot S, Cowans D, Bevan DH, Treasure T. Pre-operative aspirin decreases platelet aggregation and increases postoperative blood loss-a prospective, randomised, placebo controlled, double-blind clinical trial in 100 patients with chronic stable angina. Eur J Cardiothorac Surg. 1994;8:404-9.

7. del Campo Abadiano JA, Heredia y Perez I, Ramos Cano VH, Barragan Garcia R. Evaluation of predisposing factors for mediastinal bleeding in myocardial revascularization surgery. Role of acetylsalicylic acid, other platelet adhesion inhibitors, and anticoagulants. Arch Cardiol Mex. 2004;74:118-25.

8. Ferraris VA, Ferraris SP, Joseph O, Wehner P, Mentzer RM Jr. Aspirin and postoperative bleeding after coronary artery bypass grafting. Ann Surg. 2002;235:820-7.

9. Munoz JJ, Birkmeyer NJ, Dacey LJ, Birkmeyer JD, Charlesworth DC, Johnson ER, et al. Trends in rates of reexploration for hemorrhage after coronary artery bypass surgery. Northern New England Cardiovascular Disease Study Group. Ann Thorac Surg. 1999;68:1321-5.

10. Hockings BE, Ireland MA, Gotch-Martin KF, Taylor RR. Placebocontrolled trial of enteric coated aspirin in coronary bypass graft patients. Effect on graft patency. Med J Aust. 1993;159:376-8.

11. Chesebro JH. Effect of dipyridamole and aspirin on vein graft patency after coronary bypass operations. Thromb Res Suppl. 1990;12:5-10.

12. Branca P, McGaw P, Light RW. Factors associated with prolonged mechanical ventilation following coronary artery bypass surgery. Chest. 2001;119:537-46.

13. Reber G, Boehlen F, Fontana P. Study of primary hemostasis in vitro with the Platelet Function Analyzer (PFA-100). Rev Med Suisse Romande. 2003;123:491-4.

14. Undas A, Sanak M, Musial J, Szczeklik A. Platelet glycoprotein IIIa polymorphism, aspirin, and thrombin generation. Lancet. 1999;9157: 982-3.

15. Tabuchi N, Huet RC, Sturk A, Eijsman L, Wildevuur CR. Hemostatic function of aspirin-treated platelets vulnerable to cardiopulmonary bypass. Altered shear-induced pathway. J Thorac Cardiovasc Surg. 1995;110:813-8.

16. Peters RJ, Mehta SR, Fox KA, Zhao F, Lewis BS, Kopecky SL, et al. Effects of aspirin dose when used alone or in combination with clopidogrel in patients with acute coronary syndromes: observations from the Clopidogrel in Unstable angina to prevent Recurrent Events (CURE) study. Circulation. 2003;108:1682-7.

17. Levi M, Cromheecke ME, de Jonge E, Prins MH, de Mol BJ, Briet E, et al. Pharmacological strategies to decrease excessive blood loss in cardiac surgery: a meta-analysis of clinically relevant endpoints. Lancet. 1999; 354:1940-7.

18. Vander Salm TJ, Kaur S, Lancey RA, Okike ON, Pezzella AT, Stahl $\mathrm{RF}$, et al. Reduction of bleeding after heart operations through the prophylactic use of epsilon-aminocaproic acid. J Thorac Cardiovasc Surg. 1996;112:1098-107. 